This article was downloaded by: [Gogonas, Nikos]

On: 2 March 2009

Access details: Access Details: [subscription number 909172540]

Publisher Routledge

Informa Ltd Registered in England and Wales Registered Number: 1072954 Registered office: Mortimer House, 37-41 Mortimer Street, London W1T 3JH, UK

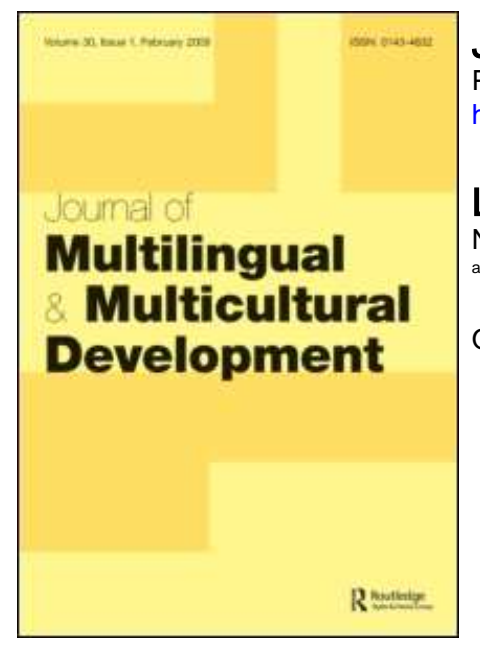

Journal of Multilingual and Multicultural Development

Publication details, including instructions for authors and subscription information:

http://www.informaworld.com/smpp/title content=t794297829

\title{
Language shift in second generation Albanian immigrants in Greece
}

Nikos Gogonas a

a Napoleontos 28, Athens, GR, Greece

Online Publication Date: 01 March 2009

To cite this Article Gogonas, Nikos(2009)'Language shift in second generation Albanian immigrants in Greece',Journal of Multilingual and Multicultural Development,30:2,95 - 110

To link to this Article: DOI: $10.1080 / 01434630802307908$

URL: http://dx.doi.org/10.1080/01434630802307908

\section{PLEASE SCROLL DOWN FOR ARTICLE}

Full terms and conditions of use: http://www.informaworld.com/terms-and-conditions-of-access.pdf

This article may be used for research, teaching and private study purposes. Any substantial or systematic reproduction, re-distribution, re-selling, loan or sub-licensing, systematic supply or distribution in any form to anyone is expressly forbidden.

The publisher does not give any warranty express or implied or make any representation that the contents will be complete or accurate or up to date. The accuracy of any instructions, formulae and drug doses should be independently verified with primary sources. The publisher shall not be liable for any loss, actions, claims, proceedings, demand or costs or damages whatsoever or howsoever caused arising directly or indirectly in connection with or arising out of the use of this material. 


\title{
Language shift in second generation Albanian immigrants in Greece
}

\author{
Nikos Gogonas* \\ Napoleontos 28, Athens, GR, Greece \\ (Received 17 December 2007; accepted 24 June 2008)
}

\begin{abstract}
Albanian immigration to Greece started in the beginning of the 1990s and the second generation of Albanian immigrants is a recent phenomenon. This paper presents the findings of research investigating language maintenance/shift among second generation Albanian immigrants in Athens using as main informants adolescents of Albanian origin. Quantitative and qualitative data on children's language competence and on patterns of language use within Albanian households indicate that the Albanian ethnolinguistic group is undergoing rapid language shift. For the social psychological dimension of the study, data were gathered by utilising the concept of ethnolinguistic vitality and some items of the subjective vitality questionnaire (SVQ). The SVQ data indicate low vitality perceptions among second generation Albanian immigrants. Finally, while Albanian parents express positive attitudes to language maintenance, in practice many do not take the necessary measures for intergenerational language transmission.
\end{abstract}

Keywords: immigrants; language shift; ethnolinguistic vitality

\section{Introduction}

Greece is a recent destination country for immigrants, after having exported immigrants mainly to Australia, the USA and Western Europe for many years. According to the 2001 census, the total migrant population in Greece was about 800,000 people. Of them, about $60 \%$ come from neighbouring Albania. However, the linguistic profile of Greece was characterised by diversity, even before the recent influx of migrants. Ever since the first decades of the independent Greek state, the nation has been defined with reference to common ancestry (Kitromilides 1983; Veremis 1983, 1990), culture and language (Kitromilides 1990). Greek national consciousness was 'constructed' throughout the 19th century with reference to the irredenta, namely the regions inhabited by Greek-speaking Christian Orthodox populations that had not been included in the Greek state at the moment of its creation. The Lausanne Treaty in 1923 contributed to the homogenisation of the Greek population through the minority population exchange between Greece, on the one hand, and Turkey and Bulgaria on the other. Part of this homogenisation process included the assimilation of ethnolinguistic and religious minorities that remained in Greece, such as speakers of Pomak (a variety related to Bulgarian, spoken by the Pomak Muslim minority of western Thrace), Romany (the language of the Rom or Gypsies, related to dialects spoken in northern India), Ladino (a Romance language

*Corresponding author. Email: nikgog@hotmail.com 
spoken by the Jewish community in Greece), Vlach (related to Rumanian and spoken by communities in Thessaly and in the area of Pindos), Arvanitika (related to Albanian and spoken by communities in the area of Thebes and Athens, as well as in the Peloponnese and some of the islands) and Slavika (related to Macedonian and spoken by communities in the area of western Macedonia) (Sella-Mazi 2001; Trudgill 2002). From the aforementioned languages, Turkish is the only one that is officially recognised in Greece as a minority language, spoken by the Turkish-speaking minority of western Thrace, a minority that is protected by the terms of the Treaty of Lausanne (1923).

Greece's resistance to acknowledge the existence of minorities within its territory can be seen as the result of the fact that most of them have been identified with territorial claims by neighbouring countries with which geo-political relations have always been tense (Rozakis 1996) The homogenisation process of the Greek state towards the above-mentioned minorities has been generally successful. For example, both the Vlachs and the Arvanites demonstrate a very strong Greek national identity, and their feelings of connection with other nations are, for the most part, nonexistent (Trudgill 2002). This is further illustrated by vitality measurements of the respective languages. Arvanitika and Vlach have been classified as having low vitality (Sella-Mazi 2001).

The above background information may help explain why efforts to establish strategies and means for the maintenance of minority languages in Greece are in their infancy, especially insofar as these languages are related to 'traditional enemies' of the country (such as Albanians). Until now, the only concern that Greek political and educational institutions have voiced is the successful teaching of Greek as a second language, while issues raised by supporters of intercultural and antiracist education, from both the academic and the educational contexts, have minimal and sporadic impact on the mainstream educational system, depending on the interest and enthusiasm of individual educators. As far as academic research is concerned, issues of language contact and bilingualism in Greece concern both language and education experts. Evidence of this is provided by the work of Greek researchers, such as Antonopoulou, Tsangalides, and Moumtzi (2000), Damanakis (1997), Georgoyannis (2006), Kiliari (1997), Paleologou (2004), Skourtou (2000, 2002), Tressou and Mitakidou (2003, 2007) and Tsokalidou (2005). However, language maintenance/ shift has hardly been researched. The limited available research evidence indicates language shift in second generation Albanians (Hatzidaki 2005). In the present study the language shift phenomenon in second generation Albanians in Greece is examined through a social psychological approach, by applying the Ethnolinguistic Vitality Theory.

\section{Ethnolinguistic vitality}

Giles, Bourhis, and Taylor (1977) proposed the model of ethnolinguistic vitality to develop a framework for the role of socio-structural variables in inter-group relations, cross-cultural communication, second language learning, mother tongue maintenance, language shift and loss. The vitality of an ethnolinguistic group is defined as 'that which makes a group likely to behave as a distinctive and active collective entity in inter-group situations' (Giles, Bourhis, and Taylor 1977, 308). According to Giles, Bourhis, and Taylor (1977) status, demographic, institutional support and control factors combine to make up the vitality of ethnolinguistic 
groups. Low-vitality groups are most likely to go through linguistic assimilation and would not be considered a distinctive collective group (Bourhis, Giles, and Rosenthal 1981). On the other hand, high-vitality groups are likely to maintain their language and distinctive cultural traits in multilingual settings.

Bourhis, Giles, and Rosenthal (1981) propose that group members' perceptions of each of the vitality variables (demographic, status and institutional support) may be as important as the group's objective vitality. As discussed by Johnson, Giles, and Bourhis (1983), the construct of perceived or subjective vitality stems from the need to take into account individuals' perceptions of the societal conditions which impinge upon them as members of their own group relative to salient out-groups. As a psychological construct, it was proposed that subjective vitality perceptions can play a mediating role in accounting for the group members' inter-group strategies, language attitudes/behaviours and degree of in-group identification.

The subjective vitality questionnaire (SVQ) has been proposed as a means of measuring group members' assessment both of their in-group vitality and of the vitality of out-groups. The questionnaire measures the three main factors which contribute to a group's overall vitality (demographic strength, status and institutional support) and it also elicits subjects' perceptions on the degree of contact among ethnic groups. For EV studies, see Bourhis and Sachdev (1984), Giles and Johnson (1987), Giles, Rosenthal, and Young (1985), Kraemer and Olshtain (1989), Yagmur (2004), Yagmur and Kroon (2003) and Ytsma, Angels Viladot, and Giles (1994). For critiques of the theory, see Fishman (2001) and Husband and Saifullah Khan (1982).

\section{Objective data on Albanian ethnolinguistic vitality in Greece}

\section{Demography}

Albanian immigration to Greece started in the early 1990s, immediately after the collapse of the 45-year Communist regime of Enver Hoxha in Albania, during which the country had been the most isolated in Europe, possibly in the world. Rates of emigration during these early years of mass exodus were particularly high among the ethnic-Greek Albanians of the southern part of the country. In 1993-1996, there was a temporary decrease in the migratory movement from Albania to Greece; in 19961997, however, the political, and then quickly the economic conditions in Albania began to deteriorate, sparking another phase of mass emigration (Korovilas 1998). Albanian migration to Greece has been clandestine, via mountain paths which cross the border in remote places (King, Iosifides, and Myrivilli 1998). Moreover, there have been massive deportations of Albanian immigrants (and subsequent re-entry of the deported migrants back into Greece). Fakiolas (2003) has documented the massive scale of these repatriations: during the 1990s and early 2000s, the annual average of enforced returns was 230,000 Albanians. Barjaba and King (2005) estimate that there could be around 600,000 Albanians (a combination of documented and undocumented persons) living in Greece by 2005. Considering that the total Greek population is less than 11 million, this is a considerable presence, equivalent to more than $5 \%$ of the country's population. Albanian migration to Greece continues today, albeit on a smaller scale (Vullnetari 2007).

Illegal Albanian immigrants had the opportunity to regularise their status in Greece for the first time in 1998. Two more regularisation programmes have taken place since, one in 2001 and one in 2005. According to data from the Greek Ministry 
of Interior, in October 2007, 300,000 Albanians had valid stay permits (Antigone website 2007). At this point it should be noted that even regularised migrants are in a state of 'semi-legality', as residence permits for migrants who have been legally in Greece for less than 10 years are renewed for one or two years only. Moreover, due to the immense delay of the process, by the time the permit is issued, they have to apply again because it is nearly expired (Triandafyllidou and Maroufof 2008).

\section{Status}

Albanians are the largest immigrant group in Greece which has been one factor in the negative attitudes towards them. The Greek reaction to the immigration of more than half a million Albanians since 1990 has been constructed for the most part by the media, which has played a crucial role in fashioning images of Albania and the Albanians. These have been generally negative. Initially welcomed, Albanians quickly became denigrated with a series of highly negative stereotypes. This vilification has been very severe, reflecting the massive presence of Albanian migrants, the lack of other prominent migrant nationalities, and the antagonistic history of GrecoAlbanian relations during and since the Ottoman Empire. Kapllani and Mai (2005) add another dimension to this stigmatisation. They posit three main overlapping themes that are displayed in the way that the Greek media has presented the Albanian migrants: as inherently criminal, as poor and backward by nature and destined to remain thus, and as the 'invader' and 'traditional enemy' by reason of their ethnicity and religion. This 'othering' of Albanians can be traced in Greece's collective memory of its own past of poverty combined with authoritarianism and resulting in emigration. The Greek reaction is also made more complicated by the presence, amongst the immigrants, of large numbers of ethnic-Greek Albanians who are treated more favourably than 'other' or 'true' Albanians, both in terms of their rights in Greece (automatically given visas and work permits) and the attitudes of the Greek population (Triandafyllidou and Veikou 2002). The standard image of Albanians in Greece has for long been of 'cunning, primitive, untrustworthy' ... 'dangerous' people and 'criminals' (Lazaridis and Wickens 1999, 648). The topic of Albanian criminality has been obsessively pored over by the Greek media, with the result that public opinion has been fundamentally changed.

The stereotypical identifications discussed above have led many Albanian migrants to take recourse to subversive strategies in order to avoid individual exclusion and to generate trust with the host community (Mai and SchwandnerSievers 2003). Baptism and patterns of name changing are two examples of individual Albanian coping strategies (Hart 1999; Hatziprokopiou 2003). The practice of name changing and hiding religious affiliation, apart from having been used as a 'survival' strategy by Albanians in Greece, entails a certain blurring of the ethnic boundary between Greek and Albanian identity (Pratsinakis 2005). Albanians with a Greek name who also speak Greek can pass as Albanians of Greek origin in order to receive the preferential treatment that ethnic-Greeks of Albania receive in Greece.

\section{Institutional support}

Until the early 2000s, no particular measures for the integration of migrants had been undertaken. Regarding National Insurance and social protection, law 2910/2001 recognised equal rights, as they apply to Greek citizens, for foreign nationals legally 
resident in Greece. It was only in 2002 that the government launched a set of measures aiming specifically at integration for the first time. The 'Action Plan for the Social Integration of Immigrants for the Period 2002-2005' includes provisions for the training, labour-market integration and health care of immigrants, the establishment of local centres of social support, and the promotion of cultural exchanges among the various communities. Up to now, the outcomes of any implementation of the plan remain obscure (Hatziprokopiou 2006). However, in the summer of 2007 the Ministry of Interior launched Estia, a major policy programme which aims to evaluate the present situation regarding immigrant integration, record European practices and set the priorities for the national strategy for immigrant integration (Triandafyllidou and Maroufof 2008).

A channel through which Albanian immigrants in Greece can be said to participate in civic life is immigrant associations, often in interaction with citizens and institutions of the host country. Most associations were created after the first regularisation programme of 1998. A major concern of the associations has been the preservation of Albanian identity against prejudice and racism. Of interest also is the insistence of associations on their lack of a narrow political agenda, emphasising their cultural and identity goals. This is partly explained by the communist past, but also by their marginalisation in Greek sociopolitical agendas (Hatziprokopiou 2006). Transnational socio-political spaces are being created nonetheless, as narratives of 'homeland' are shared and reproduced. These organisations also provide for the socialisation of the second generation, where Albanian language classes can have an important place. However, Albanian mother tongue classes operate only in a few Greek cities (Thessaloniki, Volos) while no classes have been recorded in Athens. Moreover, participation of Albanian immigrants in Greece in migrant organisations is still very low, when compared to other immigrant groups in Greece and in other countries. Hatziprokopiou (2006) records a participation percentage of $18 \%$ among Albanians in Thessaloniki. There is, though, an important distinction one should make. Hatziprokopiou (2006) in his Thessaloniki study, found that while migrant associations are poorly developed among Albanians, ethnic or cultural unions have emerged since the very beginning, initially assisted by, or incorporated into, existing organisations. Ethnic Greeks and Vlachs, in some cases people originating from the same area, appear much more disposed to form and participate in collective organisations, partly due to their smoother integration patterns, as well as because of strong perceptions of identity dating back to their years in Albania.

Greek law on intercultural education (1996) as well as a series of ministerial circulars make provision for mother tongue teaching as regards migrant languages by bilingual teachers from the pupils' countries of origin. Despite these provisions, mother tongue teaching has so far been implemented only in a limited number of schools in the country on an experimental basis, while the Ministry of Education does not approve mother tongue teaching. Moreover, there is not any fully fledged Albanian school in Athens at the moment. Albanian language media are readily accessible to Albanian immigrants in Greece. Apart from 17 daily newspapers that circulate in Albania, one can find three Albanian newspapers published in Greece. Weekly magazines and journals published in Albania are also available. 


\section{The present study}

The main aim of this study is to assess whether there is language shift among speakers of Albanian in Greece following a social-psychological approach. The study addresses the following research questions: (1) how important is language shift in the children of Albanian immigrants? (2) what are some of the factors that affect this shift?

\section{Informants}

The sample consists only of ethnic Albanians, i.e. no ethnic-Greeks of Albania participate. Of the 70 Albanian pupils who participated in the questionnaire study, 39 are boys and 31 are girls and their mean age is 14.2 years. In this paper we define the second generation as children born in the host country of one or more immigrant parents or those who arrived before primary-school age (Portes and Zhou, 1993; Thomson and Crul, 2007). From the 'second generation' Albanian pupils of this study only one was born in Greece, while the majority $(55 \%)$ migrated to Greece between 1995 and 1998. The Albanian parents' mean age is 41.6 and at the time of the interview they had been in Greece on average for 11.5 years.

\section{Data collection procedures}

Data collection lasted from January to December 2005. The procedure for carrying out the Albanian pupils' questionnaire survey was as follows: permission was obtained from the Pedagogical Insitute, a board of the Greek Ministry of Education which has to approve studies that take place in state schools, before proceeding to the actual questionnaire study in eight schools of the greater Athens area. About 10 Albanian pupils from each school completed questionnaires. In the end 70 questionnaires by Albanian pupils were used for the analysis. Moreover, 16 Albanian pupils from the same schools were interviewed.

\section{Instruments}

The pupils' questionnaire consists of (a) some questions of Bourhis, Giles, and Rosenthal's (1981) subjective ethnolinguistic vitality questionnaire in adapted form. Due to the fact that the SVQ is a cognitively demanding questionnaire, and the mean age of the sample of the present study is around 14.2 years, the questions have been simplified and several of them have been omitted altogether after a pilot study in September 2004. Of the 22 questions of the standard SVQ, 10 were used in the present study. Certain questions proved too difficult for 14-year-olds to handle during the pilot (e.g. estimation of birth rates). Questions on estimations of the wealth/economic power of ethnoliguistic groups were thought to be too sensitive in an adolescent setting, while the question on 'use of languages in religious worship' was 'censored' by the PI, demonstrating thus the hegemony of Christian Orthodoxy in Greek society and education. As regards questionnaire layout, it was simplified after the questionnaire was tried in the pilot study: the number of choices on each item were reduced from seven to four, and the original numerical categories were verbalised using the adverbs 'extremely', 'a lot', 'a little' and 'not at all'. Sociolinguistic information on: self-evaluation of language skills in ethnic language 
and in Greek; language use in the home and at school. Albanian pupils were asked to evaluate their language competence in Greek and the parental language on a fourpoint scale, ranging from 'not at all' to 'very well', in four language skills, namely speaking, understanding, writing and reading. In my interviews with Albanian pupils I elicited sociolinguistic information on their language choices with parents, siblings, older relatives and conational friends, and I also asked to what extent they understand and communicate in their mother tongue in visits to the home country.

The aim of the interviews with Albanian parents was to examine their involvement in transmitting the mother tongue to their children through the use of Albanian with their children at home, through teaching them the ethnic language or encouraging them to attend mother tongue classes, organising trips to the home country, introducing videos and songs from the home country into the home, and providing their children with reading material in the home language.

The software package, Statistical Package for Social Sciences (SPSS) was used to analyse the quantitative data. This was able to extract simple frequencies, e.g. how many pupils belonged to each age group; do cross-tabulations, e.g. find out the gender composition of each age group; and use the inputted data to create new categories, e.g. pupils who had read a book in Albanian in the last week.

\section{Limitations}

Certain factors have to be taken into account in the analysis of the pupils' survey. The fact that the study was carried out in the Greek language and by a Greek national as well as the fact that the study took place in Greek schools, may have had a bearing on their responses both with reference to self-assessments of linguistic skills and language use. Another reason why results on language competence and use have to be treated with some caution is the high element of subjectivity attached to selfassessment (McKinney and Priestly 2004). Indeed, although Lemmon and Goggin $(1989,142)$ found that self-ratings adequately reflect language abilities, they conclude that 'subjects may not accurately assess their language skills, and may rely too heavily on inappropriate comparison groups or show a social desirability bias'; Delgado et al. (1999) found that the validity of self-assessments varied on different tasks, that they may be susceptible to a social desirability bias, and that the stimulus language may affect responses.

The fact that I am a Greek national, i.e. a member of the host country, implied that I would have to take measures in order to ensure a certain degree of 'trust' with immigrant participants, as interviewees might not have felt comfortable in expressing their true feelings to a member of the host society in an interview taking place in the host country. This is the reason why the intermediation of a person who acted as 'referee' for me as the researcher, was necessary in contacting immigrants. Moreover, the fact that I have communicative skills in the Albanian language may have helped me, to some extent at least, to 'break the ice' and get more of an 'insider status' during interviews with Albanian parents. The good Greek language skills of Albanian interviewees did not make my use of Albanian necessary.

Another limitation of the study relates to the 'gatekeeper' function of school headteachers in selecting the pupils who participated in the study, following institutional guidelines imposed by the PI. Furthermore, headteachers employed certain (arbitrary) criteria in their selection: some chose underachievers and trouble makers, the rationale behind this choice being that they do not contribute anything to 
their class anyway, so they might as well miss a lesson. Other headteachers, however, seemed to reason in the opposite way. They chose top-scoring pupils who - in their opinion - would have much more to contribute to the study compared to others. This variation of criteria employed by headteachers in the selection of pupils has a positive aspect in that it has led to a range of pupil 'types'.

Furthermore, headteachers were not authorised to provide me with contact details of pupils' families. Therefore, I had to trace the Albanian adults' sample separately, making sure that the parents I interviewed were from the same general social background and migration circumstances represented at the school catchment areas, and that their children's school experiences were similar to the ones I had surveyed.

\section{Results}

The results presented below refer to (1) perceptions of ethnolinguistic vitality; (2) Albanian pupils' self-assessments of language competence in Albanian and Greek and language choices with various interlocutors: both of these sets of data indicate language shift into Greek; (3) factors affecting language maintenance/shift in Albanian households, namely parents' language choices, parents' attitudes to mother tongue maintenance and mother tongue teaching, availability of audiovisual and reading material in the home language and frequency of visits to the home country.

\section{Subjective ethnolinguistic vitality questionnaire}

The findings derived from SEVQ (Table 1) suggest that Albanian vitality is perceived rather low by Albanian speakers in Athens, while Greek vitality is perceived to be very high. Among all 10 variables in the questionnaire, Greek vitality is rated higher than Albanian vitality. The highest differences are noted in the vitality of the Albanian language in mass media and in schools. Moreover, Albanian pupils do not appear to be making serious efforts to raise in-group vitality vis-à-vis the majority Greek group. The only dimensions in which they try to attenuate their group

Table 1. Subjective ethnolinguistic vitality ratings of Albanian pupils for Albanian and Greek vitalities.

\begin{tabular}{lcc}
\hline & $\begin{array}{c}\text { Albanian vitality } \\
\text { Means }^{\mathrm{a}}\end{array}$ & $\begin{array}{c}\text { Greek vitality } \\
\text { Means }\end{array}$ \\
\hline $\begin{array}{l}\text { Demographic factors } \\
\text { Proportion of population }\end{array}$ & 2.40 & 1.42 \\
$\quad$ Albanian/Greek immigration patterns & 1.87 & 1.85 \\
Status & 2.63 & 1.14 \\
$\quad$ Perceived group status & 2.54 & 1.16 \\
Perceived language status locally & 2.46 & 1.67 \\
Perceived language status internationally & & \\
Institutional support/control & 2.77 & 1.26 \\
Amount of Greek/Albanian language in mass media & 3.69 & 1.17 \\
Amount of Greek/Albanian language in schools & 2.64 & 1.14 \\
Amount of Greek/Albanian political power & 1.86 & 1.19 \\
Pride of cultural history & 2.67 & 1.17 \\
Evaluation of group's cultural representation & & \\
\hline
\end{tabular}

${ }^{\text {a }}$ Scores range from 4 to 1 : the lower the score, the higher the perceived ethnolinguistic vitality. 
difference from the Greek group in an attempt to gain positive distinctiveness (Tajfel and Turner 1979) are 'pride of cultural history' and 'proportion of population'. Albanian pupils' rating of their ingroup on proportion of population seems exaggerated, as, according to the objective vitality data Albanians in Greece do not constitute more than $5 \%$ of the total of the Greek population. The results indicate that Albanian adolescents are well aware of the subordinate position of their ethnolinguistic group in Greek society as a result of the widespread stigmatisation this group has suffered, and the minimal institutional support the group is offered for its language in the country. Overall, their perceptions of ethnolinguistic vitality seem to be congruous with the group's objective vitality, discussed above.

\section{Data indicating language shift}

\section{Albanian children's language skills}

This section examines the linguistic proficiency of Albanian pupils in the parental language and in Greek from quantitative data reported by the informants themselves as well as from qualitative data, through interviews with Albanian pupils and parents.

The results in Table 2 show considerable differences in the language skills reported for the two languages by Albanian pupils and an overall dominance of Greek over Albanian in the pupils' assessment of their linguistic repertoire. However, the most striking difference in Albanian pupils' language skills in the two languages concern literacy. Thus, while $98.6 \%$ of pupils report fair or very good reading skills in Greek, only half report similar skills in the Albanian language. An even bigger difference is noted in writing ability: $98.5 \%$ report writing in Greek fairly or very well, while only $32.8 \%$ can write fairly or very well in Albanian. As is discussed later, this

Table 2. Albanian pupils' self-assessments of Greek and Albanian language skills (\% data, $N=70$ ).

\begin{tabular}{lcc}
\hline Skills & Greek & Albanian \\
\hline Understanding & & \\
Very well & 91.4 & 58.6 \\
Fairly well & 8.6 & 25.7 \\
Not very well & - & 14.3 \\
Not at all & - & 1.4 \\
Speaking & & \\
Very well & 88.6 & 42.9 \\
Fairly well & 11.4 & 34.3 \\
Not very well & - & 12.9 \\
Not at all & - & 10.0 \\
Reading & & \\
Very well & 85.7 & 17.1 \\
Fairly well & 12.9 & 32.9 \\
Not very well & 1.4 & 20.0 \\
Not at all & - & 30.0 \\
Writing & 71.4 & 11.4 \\
Very well & 27.1 & 21.4 \\
Fairly well & 1.4 & 30.0 \\
Not very well & - & 37.1 \\
Not at all & & \\
\hline
\end{tabular}


lack of literacy in Albanian is a result of the lack of mother tongue attendance by Albanian pupils.

The picture that emerges from the qualitative data regarding Albanian pupils' language skills largely supports the results of Table 2. Of the 16 Albanian pupils who were interviewed, the majority claim better speaking and understanding than reading and writing skills in Albanian, especially the ones who migrated to Greece recently. Some pupils, however, seem to 'hide' their knowledge of Albanian. This tendency on the part of Albanian pupils to avoid speaking Albanian is best explained as a reaction to the stigmatisation of their ethnic group, discussed earlier. The Albanian pupils, not wishing to associate with a stigmatised group and language, downplay their knowledge of Albanian, and consequently use Greek whenever they have the opportunity to do so. The following excerpt from an interview with an Albanian mother clarifies this tendency on the part of some Albanian children to distance themselves from the Albanian language:

When my youngest daughter was at the kindergarten she came home from school very sad. Then, her elder sister addressed her in Albanian. The younger one then, shouted at her angrily: 'Don't speak to me in Albanian. I don't understand Albanian! Can't you understand this?' The child was ashamed of her language because she had felt a racist atmosphere at school. (Albanian mother, 40)

The examination of the language skills of Albanian pupils indicates rapid language shift into Greek. More evidence of language shift in the Albanian second generation are provided in the next section on language choice.

\section{Albanian children's language choices}

Albanian children use mostly the ethnic language with adults (mother, father, older relatives) while using Greek with age mates (siblings and friends). Table 3 sets out the relevant data from the Albanian pupil questionnaire.

Albanian children make more use of Greek with their mothers and Albanian with their fathers. This may imply a higher orientation towards language maintenance on the part of Albanian fathers vis-à-vis Albanian mothers.

Concerning the pupils' language choices with adult relatives, we note a similar pattern as in their linguistic interactions with parents. Although Greek is used to an extent, the ethnic language dominates.

Moreover, as Table 3 shows, the majority of Albanian pupils speak mostly or only in Greek even with their Albanian friends (52.8\%). The same pattern is noted when it

Table 3. Albanian children's language choices with various interlocutors ( $\%$ data, $N=70)$.

\begin{tabular}{lccccc}
\hline Options & $\begin{array}{c}\text { Child and } \\
\text { mother }\end{array}$ & $\begin{array}{c}\text { Child and } \\
\text { father }\end{array}$ & $\begin{array}{c}\text { Child and adult } \\
\text { relatives }\end{array}$ & $\begin{array}{c}\text { Child and } \\
\text { siblings }\end{array}$ & $\begin{array}{c}\text { Child and } \\
\text { Albanian } \\
\text { friends }\end{array}$ \\
\hline $\begin{array}{l}\text { Mostly/only Greek } \\
\text { Equally Greek and } \\
\text { Albanian }\end{array}$ & 32.4 & 24.6 & 28.6 & 51.4 & 52.8 \\
$\begin{array}{l}\text { Mostly/only } \\
\text { Albanian }\end{array}$ & 33.3 & 40.6 & 37.1 & 32.9 & 27.1 \\
\hline
\end{tabular}


comes to children's interactions with their siblings: half of Albanian pupils speak mostly/only in Greek with siblings (Table 3).

\section{Factors affecting language maintenance/shift}

Table 4 shows results on the language choices of the parents of the Albanian pupils who participated in the questionnaire survey $(n=70)$. According to Table 4 Albanian parents address each other mostly/only in Greek while $26.1 \%$ use equally Greek and Albanian with each other. The percentages of Albanian parents who use only/mostly Greek with their children are even higher: $32.4 \%$ of mothers and $24.6 \%$ of fathers.

Only $33.3 \%$ of mothers and $34.8 \%$ of fathers use mostly/only Albanian with their children. Table 5 shows results on previous language use between Albanian parents and their children. We note a shifting tendency in the language they used to address their children when they were young, and in the language they use currently. Thus, in Table 5 we can see that $70 \%$ of Albanian mothers and about $75 \%$ of Albanian fathers spoke in Albanian to their children when they were young. A comparison of these results with the results of Table 4 shows that these percentages have dropped dramatically with the passage of time.

Data from the Albanian parents' interviews $(n=16)$ indicate that their increasing knowledge of Greek makes them gradually replace the ethnic language with Greek, even in the domain of the home. Some parents claim that they started using Greek with their children when they reached school age, as they felt they were paving the way for their children's entry to the Greek educational system. Parents are also responding to entreaties from teachers to speak to their children in Greek. In retrospect, some parents seem to regret the practice of speaking in Greek to their children. What is also interesting is that they are aware that this practice is characteristic of many parents in the Albanian community. According to the father in the next quote, addressing children in Greek is common practice among many Albanian parents:

Unfortunately this is something that happens without realising it. Sometimes I catch myself speaking in Greek to my son and then I feel bad about it, but I don't do it consciously. I even consider other Albanians who speak in Greek to their children silly but unfortunately I am one of them too. (Albanian father, 45)

Table 4. In which languages do conversations between the following interlocutors take place in your home? ( $\%$ data, $N=70)$.

\begin{tabular}{lccc}
\hline Options & Mother and father & Child and mother & Child and father \\
\hline Mostly/only Greek & 11.6 & 32.4 & 24.6 \\
Equally Greek and Albanian & 26.1 & 34.3 & 40.6 \\
Mostly/only Albanian & 62.3 & 33.3 & 34.8 \\
\hline
\end{tabular}

Table 5 . Which language did your parents mostly speak to you when you were a young child? (\% data, $N=70)$.

\begin{tabular}{lcc}
\hline Options & Mother & Father \\
\hline Mostly/only Greek & 21.4 & 17.4 \\
Equally Greek and Albanian & 8.6 & 7.2 \\
Mostly/only Albanian & 70.0 & 75.4 \\
\hline
\end{tabular}


Data from the parent sample of the present study indicate that all of the Albanian parents would like their children to know Albanian. The majority of nine parents invoke reasons of the educational value of the language; four parents favour mother tongue maintenance for repatriation reasons while three for reasons of ethnic identity. The majority of Albanian parents (14 out of 16) would like their ethnic language to be offered at Greek schools. Yet, none of the parents mentioned sending their children to attend mother tongue classes, either because 'they did not know of any school organising such classes' (12 parents) or because they 'want their children to learn good Greek' (four parents). Similarly, Albanian children from the pupils survey do not seem to have received formal tuition in Albanian as is demonstrated by their low literacy skills (Table 2). Only a third of Albanian pupils have writing ability in Albanian, while half report reading fairly/very well. According to additional data provided by my pupils survey, of those $50 \%$ who claim some reading ability in Albanian, 30\% report having learnt to read at home while $44 \%$ learnt how to read at school in Albania. Many (38\%) report reading Albanian newspapers and magazines while only $8.6 \%$ report reading Albanian course books. The majority of the parents interviewed mentioned a lack of printed material in the Albanian language in their homes, apart from Albanian newspapers (which they buy in Greece). Interestingly, grandparents are the ones who provide children with reading material in Albanian.

Some of the practices that undoubtedly foster mother tongue maintenance include watching films or listening to songs. My pupils survey data indicate that the majority of Albanian pupils last saw an Albanian film at least a year ago (55.7\%), while 50\% report listening to an Albanian song within the previous week. In the next quote an Albanian mother expresses bitterness because of her children's indifference to Albanian music and TV programmes:

At home they rarely see Albanian films. I bought a children's film for them once but they didn't like it at all. On the whole we don't have many things from Albania. I asked my daughters if they wanted a poster of the Albanian singer who will sing in the Eurovision song contest this year. They didn't want it, so I gave it to my nephews. I tried to make my daughters interested in the lyrics of the song, but they weren't. On the whole they don't show any interest and this makes me sad. (Albanian mother, 40)

Frequency of visits to the home country is considered to foster language maintenance (Borland 2006). The geographical proximity between Greece and Albania helps in this respect: most of the Albanian families drive back home. Still, Albanian immigrants cannot visit their home country whenever they want, unless they have a special travelling visa which often takes several months to be issued. Therefore, the Greek state gives them a special permission every year during Christmas, Easter and summer to travel to the home country. As a result of this, the queues at the borders during these periods are extremely long. Moreover, the heavy bureaucracy leading to long delays in passport control makes the experience of visiting home a daunting one. Some Albanian pupils, however, report that even when they are on holiday in Albania they speak only in Greek because their knowledge of Albanian is poor. They can achieve this, either by socialising with other Albanian children who live in Greece, or by finding themselves in a Greek-speaking environment, as is the case in parts of South Albania. The following quotes describe this situation:

I went to Albania four years ago and I stayed for a month. My grandparents were speaking to me in Albanian but I did not reply in Albanian because I could not understand. Luckily, my cousins who also live in Greece were there, so we were speaking Greek. (Girl, 13) 
We are originally from Tepelene, but my father is building a house in Saranda, and a lot of people speak Greek there. So, when we go in the summer, we also speak Greek there. (Boy, 13)

Quotes like the above constitute additional evidence of language shift in second generation Albanian children in Greece: the hegemony of the host language wins over the best intentions of parents and relatives, even in visits to the home country.

\section{Summary and conclusion}

Quantitative and qualitative data on children's language competence and on patterns of language use within Albanian households indicate that the Albanian ethnolinguistic group is undergoing rapid language shift. Young speakers demonstrate a clear preference for the use of Greek in interactions among themselves, while using Greek less frequently with adults. Moreover, their language choices with various interlocutors depend on their linguistic competence in the ethnic language: as this linguistic competence is declining, so is the use of the ethnic language. The analysis of the Albanian ethnolinguistic vitality suggests that the Albanian pupils are aware of the stigmatised status that their group is ascribed in Greece, and qualitative data indicate that Albanian adolescents wish to distance themselves from a stigmatised identity and language. On the other hand, although Albanian parents hold language maintenance as an ideal they do not take drastic measures to transmit the ethnic language to their children. The perceived prestige of Greek as the language of upward social mobility, and the general 'fluidity' of ethnic identity that characterises Albanian parents, leads them to embrace the Greek language at the cost of ethnic language maintenance and its transmission to the next generation.

But the use of the mother tongue and the prospects for its maintenance in the second generation are linked not only to the attitudes and efforts of the parents, but also to those of the host society. The school system in particular can play a fundamental role in encouraging the maintenance of linguistic and cultural identity, favouring them through institutionalised programmes, but also through the very orientations and attitudes the teachers transmit to the students and their families. However, there is minimal institutional support for Albanian in Greece and the Greek educational system still has far to go in fully opening itself to the diversity brought by the foreign pupils, who are primarily Albanian. As crucial as the role of the school system is, maintenance of Albanian language and culture as well as attachment to the country of origin could to some extent be promoted through the various Albanian communities in Greece. At present, however, such communities have not demonstrated strong associational forms. It seems unlikely that the second generation's relationship with Albania will assume a transnational character. As Albanian youths increasingly assimilate into Greek society, a weak connection to their ethnic language and culture will eventually decrease all meaningful links to the ancestral country. And while new, transnational lifestyles and identities are emerging in our globalised era, for these youths, Albania might well become associated with childhood memories of summer holidays, a place belonging to their parents' generation, but with little relevance to their present and future lives. In the same vein, the Albanian language may assume a purely symbolic function for the second generation. 


\section{References}

Antigone (Information and Documentation Centre on Racism, Ecology, Peace and nonviolence). Statistics by the Greek Ministry of Interior on the number of foreigners' residence permits by nationality, by 15.10.2007. http://www.antigone.gr/statistics/ (retrieved June 7, 2008).

Antonopoulou, N., A. Tsangalides, and M. Moumtzi. 2000. The teaching of Greek as a foreign/ second language. Principles-problems-perspectives [in Greek]. Thessaloniki: Centre for the Greek Language.

Barjaba, K., and R. King. 2005. Introducing and theorising Albanian migration. In The new Albanian migration, ed. R. King, N. Mai and S. Schwandner-Sievers, 1-28. Brighton: Sussex Academic Press.

Borland, H. 2006. Intergenerational language transmission in an established Australian migrant community: What makes the difference? International Journal of the Sociology of Language 180: 23-41.

Bourhis, R.Y., H. Giles, and D. Rosenthal. 1981. Notes on the construction of a subjective vitality questionnaire for ethnolinguistic groups. Journal of Multilingual and Multicultural Development 2, no. 2: 145-55.

Bourhis, R.Y., and I. Sachdev. 1984. Vitality perceptions and language attitudes: Some Canadian data. Journal of Language and Social Psychology 3: 97-126.

Damanakis, M., ed. 1997. The education of repatriated and foreign pupils in Greece. An intercultural approach [in Greek]. Athens, Greece: Gutenberg.

Delgado, P., G. Guerrero, J.P. Goggin, and B.B. Ellis. 1999. Self-assessment of linguistic skills by bilingual Hispanics. Hispanic Journal of Behavioral Sciences 21, no. 1: 31-37.

Fakiolas, R. 2003. Regularising undocumented immigrants in Greece: Procedures and effects. Journal of Ethnic and Migration Studies 29, no. 3: 535-561.

Fishman, J.A. 2001. Why is it so hard to save a threatened language? (A perspective on the cases that follow). In Can threatened languages be saved? ed. J. Fishman, 1-22. Clevedon: Multilingual Matters.

Georgoyannis, P., ed. 2006. Greek as a second/foreign language. An intercultural approach [in Greek]. 9th International Conference on Intercultural Education, 15-17 July, in University of Patras.

Giles, H., and P. Johnson. 1987. Ethnolinguistic identity theory: A social psychological approach to language maintenance. International Journal of the Sociology of Language 68: 66-99.

Giles, H., R.Y. Bourhis, and D.M. Taylor. 1977. Towards a theory of language in ethnic group relations. In Language, ethnicity and inter-group relations, ed. H. Giles, 307-48. London: Academic.

Giles, H., D. Rosenthal, and L. Young. 1985. Perceived ethnolinguistic vitality: The Angloand Greek-Australian setting. Journal of Multilingual and Multicultural Development 6, nos. 3-4: 253-69.

Hart, L. 1999. Culture, civilization and demarcation at the northwest borders of Greece. American Ethnologist 26, no. 1: 196-220.

Hatzidaki, A. 2005. Models of bilingual behaviour in Albanian pupils' families: Empirical research findings [in Greek]. Epistimes Agogis (thematic issue 2005 Bilingual pupils in Greek schools: Teaching approaches and theoretical issues), no 3, 79-102.

Hatziprokopiou, P. 2003. Albanian immigrants in Thessaloniki, Greece: Processes of economic and social incorporation. Journal of Ethnic and Migration Studies 29, no. 6: 1033-57.

2006. Globalisation, migration and socio-economic change in contemporary Greece. Processes of social incorporation of Albanian and Bulgarian immigrants in Thessaloniki. IMISCOE diss., AUP, Amsterdam.

Husband, C., and V. Saifullah Khan. 1982. The viability of ethnolinguistic vitality: Some creative doubts. Journal of Multilingual and Multicultural Development 10: 197-212.

Johnson, P., H. Giles, and R.Y. Bourhis. 1983. The viability of ethnolinguistic vitality: A reply. Journal of Multilingual and Multicultural Development 4: 255-69.

Kapllani, G., and N. Mai. 2005. 'Greece belongs to Greeks!' The case of the Greek flag in the hands of an Albanian student. In The new Albanian migration, ed. R. King, N. Mai, and S. Schwandner-Sievers, 153-72. Brighton: Sussex Academic Press. 
Kiliari, A. 1997. Foreigner in Greece. Migrants, language and social integration [in Greek]. Thessaloniki: Paratiritis.

King, R., T. Iosifides, and L. Myrivilli. 1998. A migrant's story: From Albania to Athens. Journal of Ethnic and Migration Studies 24, no. 1: 159-75.

Kitromilides, P. 1983. The Greek state as national centre. In Hellenism and Greekness: Ideological and biographical axes of Modern Greek society, ed. D. Tsaousis, 143-64 [in Greek]. Athens, Greece: Estia.

- 1990. 'Imagined communities' and the origins of the national question in the Balkans. In Modern Greece: Nationalism and nationality, ed. M. Blinkhorn and T. Veremis, 23-64. Athens, Greece: ELIAMEP.

Korovilas, J. 1998. The Albanian economy in transition: The role of remittances and pyramid investment schemes. Working Papers in Economics 28. Bristol: University of the West of England.

Kraemer, R., and E. Olshtain. 1989. Perceived ethnolinguistic vitality and language attitudes: The Israeli setting. Journal of Multilingual and Multicultural Development 10: 197-212.

Law 2413/96. 1996. Greek Education Abroad, Intercultural Education and Other Provisions.

Lazaridis, G., and E. Wickens. 1999. 'Us' and the 'Others': Ethnic minorities in Greece. Annals of Tourism Research 26, no. 3: 632-55.

Lemmon, C.R., and J.P. Goggin. 1989. The measurement of bilingualism and its relationship to cognitive ability. Applied Psycholinguistics 10: 133-55.

Mai, N., and S. Schwandner-Sievers. 2003. Albanian migration and new transnationalisms. Journal of Ethnic and Migration Studies 29, no 6: 939-48.

McKinney, M.P.L., and T. Priestly. 2004. Telling tales out of school: Assessing linguistic competence in minority language fieldwork. Journal of Multilingual and Multicultural Development 25, no. 1: 24-40.

Paleologou, N. 2004. Intercultural education and practice in Greece: Needs for bilingual intercultural programmes. Intercultural Education 15, no. 3: 317-29.

Portes, A., and M. Zhou. 1993. The new second generation: Segmented assimilation and its variants. Annals of the American Academy of Political and Social Science 530: 74-98.

Pratsinakis, E. 2005. Aspirations and strategies of Albanian immigrants in Thessaloniki. Journal of Southern Europe and the Balkans 7, no. 2: 195-212.

Rozakis, C. 1996. The international protection of minorities in Greece. In Greece in a changing Europe, ed. K. Featherstone and K. Ifantis, 95-116. Manchester: Manchester University Press.

Sella-Mazi, E. 2001. Bilingualism and society. The Greek reality [in Greek]. Athens, Greece: Proskinio.

Skourtou, E., ed. 2000. Naxos workbooks: Bilingualism [in Greek]. Rhodes, Greece: University of the Aegean.

2002. Bilingual pupils in the Greek school. In Epistimes Agogis, thematic issue 2002. Intercultural pedagogy in Greece. Practical issues and theoretical questions [in Greek], ed. M. Damanakis, 11-20. University of Crete.

Tajfel, H., and J.C. Turner. 1979. An integrative theory of inter-group conflict. In The social psychology of inter-group relations, ed. W.G. Austin and S. Worchei, 33-47. Monterey, CA: Brooks/Cole.

Thomson, M., and M. Crul. 2007. The second generation in Europe and the United States: How is the transatlantic debate relevant for further research on the European second generation? Journal of Ethnic and Migration Studies 33, no. 7: 1025-41.

Tressou, E., and S. Mitakidou, eds. 2003. Teachers talk about their experiences. Education of linguistic minorities [in Greek]. Thessaloniki, Greece: Paratiritis.

—_ eds. 2007. Minorities talk about the education of their children [in Greek]. Thessaloniki, Greece: Paratiritis.

Triandafyllidou, A., and M. Maroufof. 2008. Immigration towards Greece at the Eve of the 21st Century. A Critical Assessment. Report prepared for the IDEA project, May 2008. Athens, Greece: ELIAMEP (Unpublished).

Triandafyllidou, A., and M. Veikou. 2002. The hierarchy of Greekness. Ethnic and national identity considerations in Greek immigration policy. Ethnicities 2, no. 2: 189-208.

Trudgill, P. 2002. Sociolinguistic variation and change. Edinburgh: Edinburgh University Press. 
Tsokalidou, R. 2005. Raising 'bilingual awareness' in Greek primary schools. International Journal of Bilingual Education and Bilingualism 8, no. 1: 48-61.

Veremis, T. 1983. State and nation in Greece: 1821-1912. In Hellenism and Greekness: Ideological and biographical axes of Modern Greek society [in Greek], ed. D. Tsaousis, 59-68. Athens, Greece: Estia.

. 1990. From the national state to the stateless nation, 1821-1910. In Modern Greece: Nationalism and nationality, ed. M. Blinkhorn and T. Veremis, 9-22. Athens, Greece: ELIAMEP.

Vullnetari, J. 2007. Albanian migration and development: State of the art review. IMISCOE Working Paper No 18.

Yagmur, K. 2004. Language maintenance patterns of Turkish immigrant communities in Australia and Western Europe: The impact of majority attitudes on ethnolinguistic vitality perceptions. International Journal of the Sociology of Language 165: 121-42.

Yagmur, K., and S. Kroon. 2003. Ethnolinguistic vitality perceptions and language revitalization in Bashkortostan. Journal of Multilingual and Multicultural Development 24, no. 4: 319-36.

Ytsma, J., M. Angels Viladot, and H. Giles. 1994. Ethnolinguistic vitality and ethnic identity: Some Catalan and Frisian data. International Journal of the Sociology of Language 108: 63-78. 